\title{
Diagnosis of Bacteroides fragilis infection with counter-immunoelectrophoresis
}

\author{
O. A. OKUBADEJO, N. F. LIGHTFOOT ${ }^{1}$, AND W. G. HEWITT \\ From the Public Health Laboratory, St. Mary's General Hospital, Portsmouth, Hants, UK
}

SUMMARY In a study of 188 patients and 109 controls, the detection of antibody by counterimmunoelectrophoresis was used as a diagnostic aid in human infections with Bacteroides fragilis. It was found that positive results indicated current infection and negative results were not conclusive. The method used was simple, rapid, and easily performed in a routine laboratory, but further work is needed to enhance antigen potency.

Bacteroides fragilis strains are often cultured from routine bacteriological specimens in laboratories with adequate anaerobic technique (Leigh, 1974; Peach, 1975). At present the organisms are the most frequent cause of non-sporing Gram-negative anaerobic infection in man. During the past five years the bacteria have been isolated with increasing frequency in many laboratories. Nevertheless the pathogenicity of the isolates is often questioned because the bacteria are a major component of normal body flora (Quick, 1972; Topley, 1975; Willis, 1975). A foul-smelling discharge usually indicates anaerobic infection, but this sign may be absent in certain lesions in which $B$. fragilis is a likely infective agent. These include superficial wounds, bed sores, diabetic ulcers, salpingitis, pelvic inflammatory disease, vaginitis, episiotomy wounds, and otitis. In these infections the pathogenic role of $B$. fragilis can be ascertained either by a good response to treatment with metronidazole or by the finding of specific antibodies in the patient's serum. Recent reports indicate that antibodies can be demonstrated in sera by agglutination, haemagglutination, immunodiffusion, and immunofluorescent methods (Danielsson et al., 1972; Quick et al., 1972; Rissing et al., 1974). The reports show that IgG immunoglobulins are probably more important than IgM in the diagnosis of bacteroides infection. IgG antibodies can be detected efficiently and quickly by counter-immunoelectrophoresis (World Health Organisation, 1973); so far as we know, this technique has not been applied to the detection of antibodies in $B$. fragilis. We report a study using this method.

1Surgeon Lieutenant Commander, Royal Navy

Received for publication 29 March 1978
Patients and methods

INFECTED PATIENTS' TEST SERA

Sera were taken from patients suspected of having bacteroides infection because of positive cultures or persistent, foul-smelling, purulent lesions suggesting anaerobic infection. Initial specimens of serum were usually obtained within three days of the isolation of $B$. fragilis, and subsequent serum samples were taken whenever possible at an interval of about 7-10 days.

\section{CONTROL SERA}

Sera were also collected from patients who had no evidence of infection but had had $B$. fragilis in high vaginal swabs before a gynaecological operation (uninfected patients). Other control sera were obtained from healthy young male naval recruits and healthy female blood donors.

All sera used in this study were taken from blood given for other purposes.

COUNTER-IMMUNOELECTROPHORESIS (CIEP)

Tests were performed using Shandon Southern U77 electrophoretic apparatus with a Vokam DC power supply. The electrophoresis gel consisted of $0.75 \%$ agarose and $0.75 \%$ Noble agar (Difco) in barbitone buffer containing $40 \mathrm{~g}$ barbitone and $26 \mathrm{~g}$ sodium acetate dissolved in 4 litres of distilled water and adjusted to $\mathrm{pH} 8 \cdot 6$. This buffer was also used in the electrophoretic tank; $6 \mathrm{ml}$ of molten electrophoretic agar was layered onto clean $50 \times 75 \mathrm{~mm}$ glass slides and allowed to set. Wells, $4 \mathrm{~mm}$ in diameter and $7 \mathrm{~mm}$ apart, were cut in the gel. Antigen and serum were applied to the cathodal and anodal wells respectively. A constant current of $20 \mathrm{~mA}$ per slide was passed through the agar gel for $\mathbf{9 0}$ minutes. The current was then switched off, and the slide was 
examined for precipitin lines using incident light against a dark background.

\section{ANTIGEN}

The antigen used was prepared from the two strains of $B$. fragilis found in preliminary tests to have the widest range of antigen component (Okubadejo and Allen, unpublished work). The two strains were stored in cooked meat medium at room temperature and subcultured on Diagnostic Sensitivity Test (DST Oxoid) agar plates enriched with $10 \%$ lysed horse blood, and incubated anaerobically for 48 hours. After purity checks, the organisms were harvested from the surface of the plates and washed four times in normal saline by centrifugation at $3400 \mathrm{~g}$ for 25 minutes in a refrigerated centrifuge at a temperature of not more than $10^{\circ} \mathrm{C}$. The washed organisms were suspended in barbitone buffer at $\mathrm{pH}$ $8 \cdot 6$, the final concentration being equivalent to approximately $20 \%$ wet weight per volume. The bacteria were then disrupted by an ultrasonic disintegrator (MSE) operating with an amplitude of 6-8 microns peak to peak at $22 \mathrm{kHz}$ for a total time of 15 minutes; cooling was provided by an ice-bath. Disruption of the cells was monitored by Gram stain.

SPECIMENS, CULTURE, AND IDENTIFICATION OF BACTERIA

Bacteria were isolated from routine clinical specimens including pus, blood cultures, wound swabs, high vaginal swabs, and body fluids. The specimens were cultured on blood agar and MacConkey agar and incubated aerobically; on DST Oxoid agar containing $10 \%$ lysed horse blood and $10 \mathrm{mg}$ per litre gentamicin (DST-gentamicin); and on a blood agar plate without antimicrobials for anaerobic incubation. Cooked meat medium freshly prepared in this laboratory was also inoculated and incubated. After 48 hours' incubation at $37^{\circ} \mathrm{C}$ the plates were examined, and the cooked meat was subcultured onto blood agar and DST-gentamicin agar, which were incubated anaerobically for $\mathbf{4 8}$ hours. Anaerobiosis was obtained in Baird-Tatlock jars, the air having been replaced with a mixture of $95 \%$ hydrogen and $5 \%$ carbon dioxide. Aerobic bacteria were identified by methods described by Cowan and Steel (1974), and anaerobic bacteria as in the Anaerobic Laboratory Manual (Holdeman and Moore, 1972). Gas liquid chromatographic analysis of the products of glucose metabolism was also used for identification.

Patients from whom Bacteroides species other than $B$. fragilis were isolated were not included in this study.
Results

INFECTED PATIENTS (Table 1)

One hundred and eighty-eight patients were considered to have clinical evidence of bacteroides infection. $B$. fragilis was cultured from the lesions of 149 patients; cultures from the remaining 39 were negative.

Table 1 Comparison of CIEP results in infected patients and controls

\begin{tabular}{lccr}
\hline Infected patients & \multicolumn{1}{l}{ CIEP } & \\
\cline { 2 - 4 } & Positive (\%) & Negative (\%) & Total \\
\hline Cultures for $B$. fragilis & & & \\
$\quad$ Positive & $98(65 \cdot 8)$ & $51(34 \cdot 2)$ & 149 \\
$\quad$ Negative & $7(17 \cdot 9)$ & $32(82 \cdot 1)$ & 39 \\
Total & $105(55 \cdot 9)$ & $83(44 \cdot 1)$ & 188 \\
Controls & & & \\
Uninfected patients & $0(0)$ & $22(100)$ & 22 \\
Healthy women & $1(2)$ & $49(98)$ & 50 \\
Healthy young men & $1(2 \cdot 7)$ & $36(97 \cdot 3)$ & 37 \\
Total & $2(1 \cdot 8)$ & $107(98 \cdot 2)$ & 109 \\
\hline
\end{tabular}

\section{CONTROLS}

There were 109 controls consisting of 50 healthy female blood donors, 37 healthy young male naval recruits, and 22 preoperative gynaecological patients, from whom $B$. fragilis had been isolated but who had no clinical evidence of infection.

POSITIVE CIEP TESTS (Table 1)

One hundred and five $(56 \%)$ of the 188 infected patients' sera gave positive CIEP tests compared with two $(1.8 \%)$ of 109 controls. Of the 105 infected patients with positive CIEP, seven had negative $B$. fragilis cultures. Three of the seven had tubo-ovarian abscesses, and one had a lung abscess from which anaerobes were detected by gas chromatography of pus. The fifth patient had salpingitis and hydrosalpinx; the CIEP test was also positive on fluid collected from the pouch of Douglas during a pelvic laparoscopy. The other two had vaginal discharge with Candida albicans infection.

NEGATIVE CIEP TESTS (Table 1)

One hundred and seven (98.2\%) of 109 controls had negative CIEP tests compared with $83(44 \%)$ of 188 infected patients. However, $51(61 \%)$ of these 83 patients had $B$. fragilis in their lesions, and 20 of the 51 patients also had definite clinical evidence of $B$. fragilis infection. Seven of the 20 patients had $B$. fragilis septicaemia, four had severely infected hysterectomy wounds, four had infections associated with cholecystectomies, three had extensive appendix wound abscesses, and one had a pyometra with an 
intrauterine device in-situ.

The remaining 32 of the 83 patients with negative CIEP tests did not have $B$. fragilis in their lesions, and their infections could have been due to other organisms.

Table 2 gives details of the variety of clinical conditions from which the CIEP positive and negative sera were found, together with the results of cultures for $B$. fragilis.

TIMING OF DEMONSTRABLE ANTIBODY

As the majority of sera used in this study were taken from blood collected for other reasons, we were not able to determine the precise time relationship of antibody formation to clinical infection in many patients; however, we were able to relate them in nine patients, and details are given in Table 3. Blood was obtained from four of the nine patients before the onset of infection, and none of these sera had demonstrable antibody. However, antibody was found in all nine sera seven to $\mathbf{1 0}$ days after the onset of infection, and the CIEP test remained positive for three to six weeks. All nine patients had chemotherapy, which could have modified the production of antibody.

The antibody detected with the CIEP test cannot be quantitated, and the conventional four-fold rise in titre was not demonstrable.

\section{Discussion}

Small amounts of natural antibodies, mainly IgM,

Table 2 Details of CIEP results: infected patients

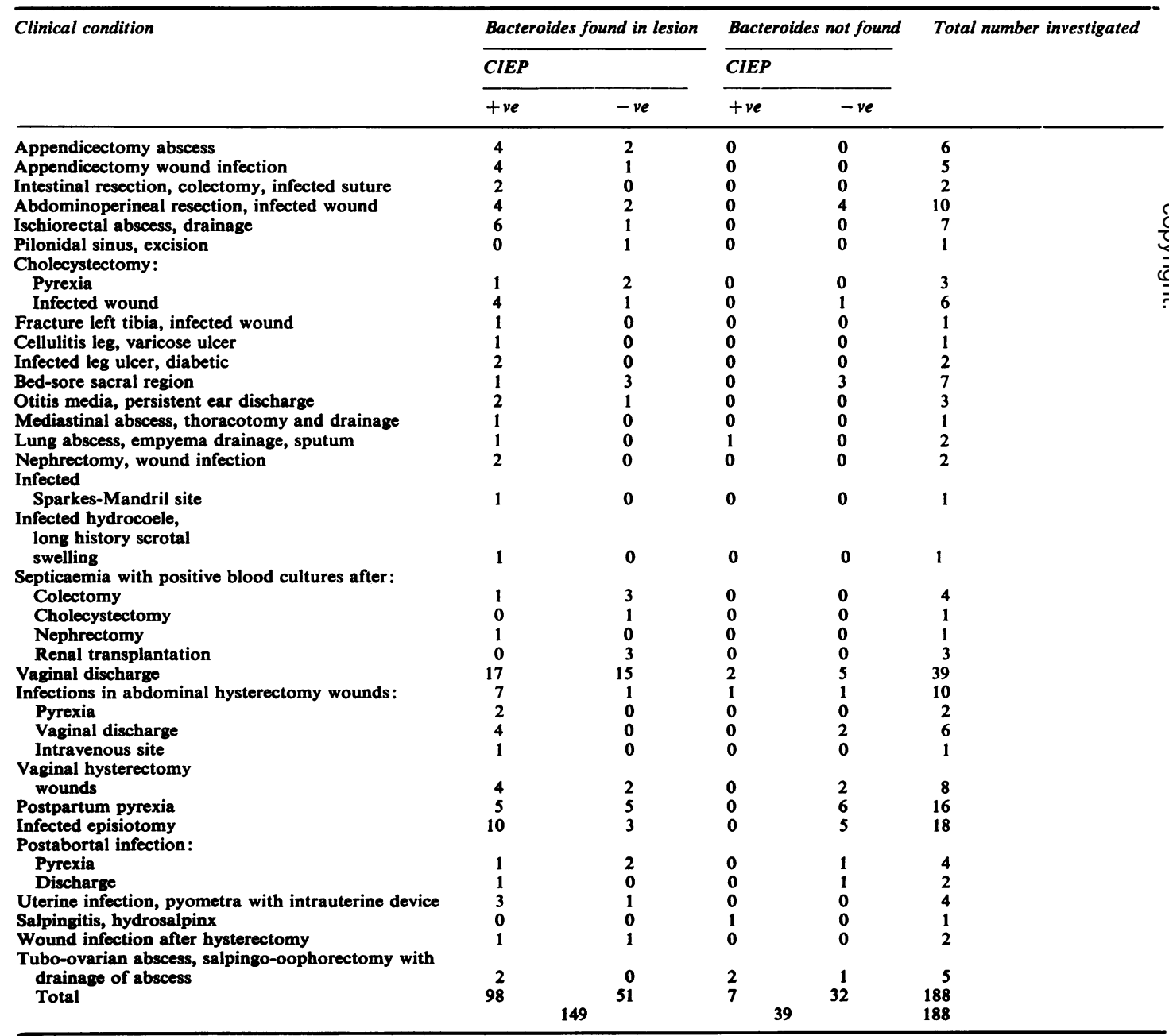


Table 3 CIEP results of sera taken before, during, and after an infection: 9 patients only

\begin{tabular}{|c|c|c|c|c|}
\hline \multirow[t]{2}{*}{ Clinical features } & \multicolumn{4}{|l|}{ Serum } \\
\hline & Before infection & Ist after infection & 2nd after infection & 3rd after infection \\
\hline $\begin{array}{l}\text { Infected appendix wound. } \\
\text { B. fragilis isolated 8th postop day }\end{array}$ & CIEP negative & $\begin{array}{l}10 \text { days postop. } \\
\text { CIEP positive }\end{array}$ & Not taken & Not taken \\
\hline $\begin{array}{l}\text { Appendix wound abscess. } \\
\text { B. fragilis isolated. Treated with metronidazole }\end{array}$ & Not taken & $\begin{array}{l}10 \text { days postop. } \\
\text { CIEP positive }\end{array}$ & $\begin{array}{l}20 \text { days postop. } \\
\text { CIEP negative }\end{array}$ & Not taken \\
\hline $\begin{array}{l}\text { Cholecystectomy wound abscess. } \\
B \text {. fragilis } E \text {. coli, and Proteus sp found in } \\
\text { abscess five days postop. Treated with gentamicin } \\
\text { and clindamycin }\end{array}$ & CIEP negative & $\begin{array}{l}7 \text { days postop. } \\
\text { CIEP positive }\end{array}$ & Not taken & $\begin{array}{l}6 \text { weeks postop. } \\
\text { CIEP negative }\end{array}$ \\
\hline $\begin{array}{l}\text { Cholecystectomy. } \\
\text { Postoperative septicaemia 5th day. Treated with } \\
\text { metronidazole }\end{array}$ & CIEP negative & $\begin{array}{l}8 \text { days postop. } \\
\text { CIEP positive }\end{array}$ & $\begin{array}{l}16 \text { days postop. } \\
\text { CIEP positive }\end{array}$ & $\begin{array}{l}3 \text { weeks postop. } \\
\text { CIEP positive }\end{array}$ \\
\hline $\begin{array}{l}\text { Total abdominal hysterectomy } \\
\text { Infected wouud and pyrexia } \\
B \text {. fragilis and } E \text {. coli in wound } 9 \text { th } \\
\text { day. Treated with cotrimoxazole } \\
\text { and gentamicin }\end{array}$ & CIEP negative & $\begin{array}{l}12 \text { days postop. } \\
\text { CIEP positive }\end{array}$ & $\begin{array}{l}19 \text { days postop. } \\
\text { CIEP positive }\end{array}$ & $\begin{array}{l}6 \text { weeks postop. } \\
\text { CIEP negative }\end{array}$ \\
\hline $\begin{array}{l}\text { Tubo-ovarian abscess. } \\
E \text {. coli and } B \text {. fragilis in abscess swab at } \\
\text { laparotomy. Treated with gentamicin and } \\
\text { clindamycin }\end{array}$ & Not taken & $\begin{array}{l}3 \text { days postop. } \\
\text { CIEP positive }\end{array}$ & $\begin{array}{l}10 \text { days postop. } \\
\text { CIEP positive }\end{array}$ & $\begin{array}{l}4 \text { weeks postop. } \\
\text { CIEP negative }\end{array}$ \\
\hline $\begin{array}{l}\text { Persistent vaginal discharge. } \\
\text { IUD in situ. Pure growth B. fragilis. Treated } \\
\text { with metronidazole }\end{array}$ & Not taken & $\begin{array}{l}3 \text { days after } \\
\text { isolation } B \text {. fragilis } \\
\text { CIEP positive }\end{array}$ & $\begin{array}{l}2 \text { weeks after } \\
\text { isolation } B . \text { fragilis } \\
\text { CIEP negative }\end{array}$ & Not taken \\
\hline $\begin{array}{l}\text { Persistent vaginal discharge. } \\
\text { B. fragilis isolated. Treated with clindamycin }\end{array}$ & Not taken & $\begin{array}{l}3 \text { days after } \\
\text { isolation } B \text {. fragilis } \\
\text { CIEP positive }\end{array}$ & $\begin{array}{l}10 \text { days after } \\
\text { isolation } B \text {. fragilis } \\
\text { CIEP positive }\end{array}$ & Not taken \\
\hline $\begin{array}{l}\text { Persistent vaginal discharge. } \\
\text { Pure growth } B \text {. fragilis. Treated with } \\
\text { metronidazole }\end{array}$ & Not taken & $\begin{array}{l}3 \text { days after } \\
\text { isolation } B \text {. fragilis. } \\
\text { CIEP positive }\end{array}$ & $\begin{array}{l}4 \text { weeks after } \\
\text { isolation } B \text {. fragilis. } \\
\text { CIEP negative }\end{array}$ & Not taken \\
\hline
\end{tabular}

are found in normal human serum using highly sensitive methods such as haemagglutination and immunofluorescent tests (Danielsson et al., 1972; Quick et al., 1972; Rissing et al., 1974). The antibody detected by the CIEP test is mainly IgG (Lightfoot, 1976), and our findings indicate that it can detect specific $B$. fragilis antibodies in the serum of patients with active infection. Antibody was detected in 105 $(56 \%)$ of 188 patients with clinical evidence of infection, and $B$. fragilis was found in all but seven of the 105 patients. The control group included 22 patients from whom $B$. fragilis had been isolated but who showed no clinical evidence of infection; antibody was not detected in any of them. These findings indicate that when specific antibody was found the patients had evidence of infection, but the mere isolation of $B$. fragilis from specimens was not directly related to infection.

There were 83 patients with clinical evidence of infection, 51 of whom had positive cultures, in whom no antibody was detected. There are three possible explanations for this. Firstly, the serum may have been taken at too early a stage of the infection, and this may be one reason for the negative CIEP result in seven of our nine patients with $B$. fragilis septicaemia. It was possible to determine the time relationship of antibody formation to infection in only nine of our patients, but the evidence suggested that antibodies could be detected seven to $\mathbf{1 0}$ days after the onset of infection. Secondly, antibody formation may have been modified in some patients by either chemotherapy or immunosuppressive therapy. Lastly, it is possible that some antigenic components are missing from the standard $B$. fragilis strains from which we prepared our antigen; the production of a more efficient antigen might result in a higher detection rate. The antigen used in our tests was a whole-cell antigen, which was likely to be bacteroides genus-specific, as described by other authors (Shinjo et al., 1971; Sonnenwirth, 1973; Hofstad, 1977).

In conclusion, therefore, we suggest that the CIEP test, which can be performed easily in most routine laboratories and is quick and inexpensive, can be of use in confirming the diagnosis of $B$. fragilis infection. Using the technique described here, a positive result confirmed infection in over half the cases, including some from whom the organsim was not isolated; a negative result was inconclusive. With further improvements in the antigen, and a more precise knowledge of the time relationship of infection to antibody production, the technique may eventually prove useful in an even higher proportion of cases.

\section{References}

Cowan, S. T., and Steel, K. J. (1974). Manual for the 
Identification of Medical Bacteria, 2nd edition. Cambridge University Press, London.

Danielsson, D., Lambe, D. W. Jr., and Persson. S. (1972). The immune response in a patient to an infection with Bacteroides fragilis ss. fragilis and Clostridium difficile. Acta Pathologica et Microbiologica Scandinavica Sect $B, 80,709-712$.

Hofstad, T. (1974). Antibodies reacting with lipopolysaccharides from Bacteroides melaninogenicus, Bacteroides fragilis, and Fusobacterium nucleatum in serum from normal human subjects. Journal of Infectious Diseases, 129, 349-352.

Hofstad, T. (1977). Cross-reactivity of Bacteroides fragilis $\mathrm{O}$ antigens. Acta Pathologica et Microbiologica Scandinavica, B, 85B, 9-13.

Holdeman, L. V., and Moore, W. E. C. (Eds). (1972). Anaerobic Laboratory Manual. Virginia Polytechnic Institute and State University, Blacksburg, Virginia.

Leigh, D. A. (1974). Clinical importance of infections due to Bacteroides fragilis and role of antibiotic therapy. British Medical Journal, 3, 225-228.

Lightfoot, N. (1976). M.Sc. Thesis, London University.

Peach, Susan (1975). Antibiotic-disc tests for rapid identification of non-sporing anaerobes. Journal of Clinical Pathology, 28, 388-391.

Quick, J. D. (1972). Ph.D. Thesis, University of Missouri.
Quick, J. D., Goldberg, H. S., and Sonnenwirth, A. C. (1972). Human antibody to Bacteroidaceae. American Journal of Clinical Nutrition, 25, 1351-1356.

Rissing, J. P., Crowder, J. G., Smith, J. W., and White, A. (1974). Detection of Bacteroides fragilis infection by precipitin antibody. Journal of Infectious Diseases, 130, 70-73.

Shinjo, T., Beerens, H., Wattre, P., and Romond, C. (1971). Classification sérologique de 131 souches de Bacteroides du groupe fragilis (Eggerthella). Annales de l'Institut Pasteur de Lille, 22, 85-100.

Sonnenwirth, A. C. (1973). Serology of Bacteroidaceae. Abstract 1. International Congress on Bacteriology, Jerusalem, 1, 183.

Topley, W. W. C. (1975). Topley and Wilson's Principles of Bacteriology, Virology and Immunity. 6th edition revised by G. S. Wilson and A. Miles. Volume 1, p. 646. Arnold, London.

Willis, A. T. (1975). A view of Bacteroides. Journal of Antimicrobial Chemotherapy, 1, 254-255.

World Health Organisation (1973). Viral hepatitis: report of a WHO scientific group. Technical Report Series, $\mathbf{5 1 2}$.

Requests for reprints to: Dr O. A. Okubadejo, Public Health Laboratory, St. Mary's General Hospital, East Wing, Milton Road, Portsmouth, PO3 6AQ, UK 